\title{
METODA PEMBELAJARAN AKUNTANSI KEPERILAKUAN DAN KORELASINYA TERHADAP PREFERENSI RISIKO MAHASISWA DALAM PEMILIHAN KARIR: SEBUAHEKSPERIMENTAL SEMU (Studi Empiris pada Program Studi Akuntansi Fakultas Ekonomi UMRAH)
}

\section{METHOD OF ACCOUNTING BEHAVIOR OF ACCOUNTING LEARNING AND CORRELATION OF STUDENT RISK PREFERENCES IN CAREER SELECTION: AN EXPERIMENTAL OF ALL (Empirical Study in the Accounting Study Program of the Faculty of Economics UMRAH)}

\author{
Jack Febriand Adel ${ }^{1}$, M. Syuzairi ${ }^{2}$ \\ 1 Universitas Maritim Raja Ali Haji - Tanjungpinang \\ 2Universitas Maritim Raja Ali Haji - Tanjungpinang \\ Email : jackfebriandadel@umrah.ac.id
}

\begin{abstract}
ABSTRAKSI
Metoda Pembelajaran yang efektif mampu mempengaruhi preferensi risiko mahasiswa. Mata kuliah Akuntansi Keperilakuan adalah mata kuliah program studi Akuntansi yang bertujuan mempelajari bagaimana akuntan berperilaku dalam menjalankan aktifitas jasanya. Penelitian ini bertujuan untuk menganalisis dan memberikan deskripsi mengenai metoda pembelajaran dan korelasinya terhadap preferensi risiko dalam pemilihan karir. Penelitian ini menggunakan metodologi penelitian eksperimental semu. Kesimpulan penelitian ini adalah Metoda Pembelajaran Akuntansi Berkorelasi Terhadap Preferensi Risiko Mahasiswa Dalam Pemilihan Karir.

Kata kunci: metode pembelajaran akuntansi keperilakuan, preferensi risiko, pemilihan karir
\end{abstract}

\begin{abstract}
Effective learning methods can influence student risk preferences. Behavioral Accounting courses are Accounting courses that aim to learn how accountants behave in carrying out their service activities. This study aims to analyze and provide a description of learning methods and their correlation to risk preferences in career selection. This research uses quasi-experimental research methodology. The conclusion of this study is the Correlation of Accounting Learning Methods Against Student Risk Preference in Career Selection.
\end{abstract}

Keywords: behavioral accounting learning methods, risk preferences, career selection 


\section{LATAR BELAKANG}

Akuntansi Keperilakuan menitikberatkan pada pembahasan mengenai bagaimana akuntan menjalankan jasa profesinya. Profesi akuntan menuntut akuntan untuk bekerja sesuai kode etik akuntan. Akuntan dapat berprofesi sebagai akuntan publik, akuntan pemerintah, akuntan manajemen, akuntan pendidik danakuntan internal perusahaan, serta beberapa posisi lain yang menuntut dibutuhkannya keahlian dan kompetensi seorang akuntan.

Metoda pembelajaran akuntansi haruslah menyesuaikan dengan tuntutan kebutuhan dunia kerja terhadap kompetensi yang harus dimiliki oleh mahasiswa akuntansi. Mahasiswa akuntansi juga haruslah memaham preferensi risiko dari setiap profesi akuntan. Preferensi risiko akan menjadi faktor penting dalam pemilihan karir oleh mahasiswa akuntansi, setelah menyelesaikan pendidikan akuntansi.

Berdasarkan uraian di atas, maka peneltian ini diberi judul "Metoda Pembelajaran Akuntansi Keperilakuan Dan Korelasinya Terhadap Preferensi Risiko Mahasiswa Dalam Pemilihan Karir: Sebuah Eksperimental Semu (Studi Empiris pada Program Studi Akuntansi Fakultas Ekonomi UMRAH)".

Berdasarkan uraian latar belakang dalam halaman sebelumnya, maka rumusan permasalahan dalam penelitian ini dijabarkan dalam bentuk pertanyaan sebagai berikut:

Apakah Metoda Pembelajaran Akuntansi Berkorelasi Terhadap Preferensi Risiko Mahasiswa Dalam Pemilihan Karir?

\section{LANDASAN TEORI}

Metoda pembelajaran Discovery Learning merupakan sistem belajar yang menuntut mahasiswa untuk mencari dan menemukan sendiri pembelajarannya menggunakan teknik pendekatan problem solving. Beberapa teknik pendekatan yang digunakan, anatar lain : 1) Simulation; 2) Problem Statement; 3) Data collection; 4) Data processing; 5) Verification; 6) Generalization.

Mahasiswa lebih aktif dalam proses pemecahan masalah, baik secara individu maupun dalam suatu kelompok belajar. Dosen berfungsi sebagai fasilitator sekaligus pembimbing dalam proses pembelajaran ini.

Langkah-langkah metoda pembelajaran discovery adalah: 1) Identifikasi kebutuhan mahasiswa; 2) Identifikasi awal terhadap pengertian konsep pengetahuan; 3) Melakukan selesksi sumber masalah; 4) Melakukan pendalaman materi terkait masalah; 5) Mempersiapkan sarpras yang diperlukan; 6) Mereviu masalah yang akan dipecahkan; 7) Mahasiswa melakukan kegiatan pemecahan masalah;8) Memberikan fasilitasi berupa informasi dan data yang diperlukan oleh mahasiswa; 9) Memberikan pendampingan berupa self analysis; 10) Mengarahkan terjadinya komunikasi maupun interaksi antar mahasiswa; 11) Membantu generalisasi hasil penemuan mahasiswa.

Metoda problem solving berorientasi pada kemampuan memecahkan masalah, baik individu maupun kelompok, dengan melalui investigasi dalam pemecahan masalah. Adapun keunggulan 
metoda problem solving antara lain : 1) Mahasiswa terlatih dalam mendesain suatu temua; 2) Berpikir inovatif dan bertindak kreatif; 3) Realistik; 4) Investigator yang baik; 5) Mampu menafsirkan dan mengevaluasi hasil pengamatan; 6) Ketepatan dalam memecahkan masalah; 7) Relevansi ilmu dan dunia kerja semakin kuat.

Metoda pembelajaran Cooperative Script mengharuskan mahasiswa untuk belajar secara berpasangan dan menggunakan komunikasi lisan dalam menyampaikan simpulan dari materi yang dipelajari. Teknis pelaksanaan pembelajaran cooperative script, antara lain : 1) Dosen melakukan rancang kelas dengan membagi mahasiswa secara berpasangan, 2) Dosen menginstruksikan mahasiswa untuk membaca dan membuat ringkasan dari materi yang dibagikan, 3) Dosen menetapkan mahasiswa yang menjadi pembicara dan pendenar.. 4) Dosen memastikan adanya komunikasi lisan antara pembicara dan pendengar, komunikasi lisan haruslah konstruktif untuk mendapatkan simpulan yang terbaik, 5) Dosen melakukan penggantian peran, 6) Dosen melakukan penarikan simpulan akhir.

\section{Preferensi Risiko}

Preferensi merupakan motivasi yang mendorong mahasiswa untuk melakukan keinginannya dalam situasi bebas memilih. Setiap preferensi manusia berfungsi untuk memuaskan suatu kebutuhan manusia, sehingga dapat digeneralisasi bahwa preferensi diharapkan berhubungan erat dengan pikiran dan perasaan manusia. Pikiran manusia cenderung bergerak dalam sektor rasional yang lebih dapat dianalisis, sedangkan perasaan manusia yang bersifat halus/tajam cenderung lebih mendambakan pemuasan kebutuhan manusia. Akal manusia berfungsi sebagai pengingat pikiran dan perasaan. Diperlukan koordinasi yang harmonis antara pikiran dan perasaan manusi, agar kebutuhan manusia bisa diatur dengan baik.

Definisi mengenai risiko adalah antara lain : 1) Risk is the chance of loss, risiko lebih mengarahkan pemahaman lebih terhadap kemungkinan timbulnya kerugian, 2) Risk is uncertainty, risiko dipahamai sebagai sesuatu yang tidak pasti akan terjadinya. Dapat diartikan juga bahwa preferensi risiko adalah sikap mahasiswa terhadap sebuah risiko. Mahasiswa dihadapkan pada 2 (dua) jenis kesediaannya menanggung resiko, yaitu: 1) Risk taker atau risk lover atau risk seeker (Pengambil Risiko), 2) Risk averter atau risk aversion (Penghindar Risiko), 3) Teori disonansi kognitif gender menyatakan bahwa perbedaan sifat dan karakter bawaan dari laki-laki dan perempuan dapat mempengaruhi perilaku dan pola pikir yang berbeda. Hal ini menjadi pertimbangan faktor terpenting selanjutnya yang berkorelasi dengan preferensi risiko dalam pemilihan karir. Riley \& Chow (1992) menemukan bahwa perilaku menghindar risiko akan lebih rendah pada laki-laki jika dibandingkan dengan perempuan. Lebih lanjut laki-laki lebih mempunyai tekanan yang lebih "thrill seeker" atau pencari sensasi, sehingga secara konsekuensi laki-laki akan cenderung untuk lebih menyukai risiko, yang akan berbanding terbalik dengan perempuan, dimana pada konteks ini perempuan menjadi lebih berperilaku menghindar risiko dibandingkan dengan laki-laki.

Pemilihan karier merupakan suatu proses atau aktivitas individu dalam usaha mempersiapkan diri untuk memasuki karier yang berhubungan dengan pekerjaan melalui suatu rangkaian proses kegiatan yang terarah dan sistematis. Pemilihan karier bagi mahasiswa jurusan akuntansi merupakan tahap awal dari pembentukan karier setelah menyelesaikan kuliah. Ada beberapa tantangan yang akan dihadapi mahasiwa dalam menentukan karier seperti 
ketidakpastian karier, pengaksesan informasi dan program pengembangan karier, tantangantantangan ekonomi dan teknologi, serta tantangan-tantangan sosial dan budaya.

\section{HASIL DAN PEMBAHASAN}

Jumlah responden yang valid dalam eksperimental semu ini adalah 67 mahasiswa/i, dengan rincian sebanyak 49 mahasiswi dan 18 mahasiswa, seperti yang dijelaskan dalam tabel berikut:

Tabel 1. Preferensi Risiko

\begin{tabular}{ccccc}
\hline Description & \multicolumn{3}{c}{ Cases } \\
\hline & \multicolumn{3}{c}{ Valid } & \multicolumn{2}{c}{ Total } \\
\hline & N & $\%$ & N & $\%$ \\
\hline Metoda Pembelajaran * Preferensi Risiko & 67 & 100 & 67 & 100 \\
\hline
\end{tabular}

Hasil eksperimental semu dengan metoda Repeated Measures Design, atau lebih dikenal dengan istilah Within Subjects Design, pada 49 mahasiswi sebanyak 39 mahasiswi mampu mengerjakan dengan hasil SAMA dan 10 mahasiswi mampu mengerjakan dengan hasil TIDAK SAMA. Sedangkan hasil eksperimen semu dengan metoda Repeated Measures Design, atau lebih dikenal dengan istilah Within Subjects Design, pada 18 mahasiswa sebanyak 7 mahasiswa mampu mengerjakan dengan hasil SAMA dan 11 mahasiswa mampu mengerjakan dengan hasil TIDAK SAMA.

Hasil eksperimen semu dengan metoda Repeated Measures Design, atau lebih dikenal dengan istilah Within Subjects Design, pada 67 responden sebanyak 46 responden mampu mengerjakan dengan hasil SAMA dan 21 responden mampu mengerjakan dengan hasil TIDAK SAMA, seperti yang disajikan dalam tabel berikut:

Tabel 2. Metoda Pembelajaran

\begin{tabular}{lccc}
\hline \multirow{1}{*}{ Metoda } & \multicolumn{2}{c}{ Preferensi Risiko } & \\
\cline { 2 - 3 } Pembelajaran & Mahasiswi & Mahasiswa & Total \\
\hline Sama & 39 & 7 & 46 \\
Tidak Sama & 10 & 11 & 21 \\
Total & 49 & 18 & 67 \\
\hline
\end{tabular}

Hasil nilai Chi-Square sebesar 10,135 dengan nilai Sig. sebesar 0,003 $<0,05$, maka dapat dikemukakan bahwa terdapat korelasi antara Metoda Pembelajaran Akuntansi dengan Preferensi Risiko.

Hal lain yang perlu diperhatikan dari output tabel Chi-Square di bawah adalah keterangan di bawah tabel yang menunjukkan berlaku atau tidaknya salah satu asumsi dari Chi-Square yang menyatakan bahwa frekuensi yang diharapkan untuk masing-masing kategori harus lebih besar dari 5. Berdasarkan tabel Chi-Square di bawah ini terlihat bahwa asumsi tersebut terpenuhi karena tidak ada sel yang memiliki frekuensi harapan di bawah 5, dan frekuensi harapan terendah juga adalah 5,64 . 
Tabel 3. Frekuensi Harapan

\begin{tabular}{lcc}
\hline Description & Value & Asymp. Sig. (2-sided) \\
\hline Pearson Chi-Square & $10.135^{\mathrm{a}}$ & .001 \\
Continuity Correction $^{\mathrm{b}}$ & 8.332 & .004 \\
Likelihood Ratio & 9.678 & .002 \\
Fisher's Exact Test & & \\
Linear-by-Linear Association & 9.984 & .002 \\
N of Valid Cases & 67 & \\
\hline
\end{tabular}

Directional Measures menggunakan 3 ukuran untuk mengukur korelasi antara kedua variabel yaitu Lambda, Goodman and Kruskal tau dan Uncertainty Coefficient. Dalam pengukuran Directional Measures terdapat pembedaan, yaitu satu variabel sebagai dependen sedangkan yang lainnya sebagai variabel independen. Pembahasan Directional Measures adalah sebagai berikut:

1. Analisis Korelasi Lambda Symmetric atau kedua variabel setara, maka besar korelasinya adalah 0,128 atau korelasi yang cukup lemah karena nilainya kurang dari 0,50. Angka signifikansinya adalah 0,521 atau di atas 0,05 yang berarti kedua variabel tidak berhubungan secara nyata.

2. Analisis Metoda Pembelajaran Dependent, dimana Metoda Pembelajaran sebagai variabel dependen (tergantung) dan Preferensi Risiko adalah variabel independennya, dengan nilai signifikansi 0,343 lebih besar daripada 0,05 (5\%), maka variabel Independen/bebas yaitu Preferensi Risiko tidak dapat memprediksi variabel dependen yaitu Metoda Pembelajaran.

3. Analisis Preferensi Risiko Dependent, dimana Preferensi Risiko sebagai variabel dependen (tergantung) dan Metoda Pembelajaran adalah variabel independennya, dengan nilai signifikansi 0,827 lebih besar daripada 0,05 (5\%), maka variabel Independen/bebas yaitu Metoda Pembelajaran tidak dapat memprediksi variabel dependen yaitu Preferensi Risiko.

4. Analisis Korelasi Goodman and Kruskal tau Metoda Pembelajaran Dependent, dimana Metoda Pembelajaran sebagai variabel dependen (tergantung) dan Preferensi Risiko adalah variabel independennya, dengan nilai signifikansi 0,002 lebih kecil daripada 0,05 (5\%), maka variabel Independen/bebas yaitu Preferensi Risiko dapat memprediksi variabel dependen yaitu Metoda Pembelajaran. Tetapi Nilai Korelasi 0,151 $<0,50$ ini artinya korelasinya lemah. Bisa dikatakan bahwa Preferensi Risiko tidak begitu memberikan dampak dalam upaya memprediksi Metoda Pembelajaran.

5. Analisis Korelasi Goodman and Kruskal tau Preferensi Risiko Dependent, dimana Preferensi Risiko sebagai variabel dependen (tergantung) dan Metoda Pembelajaran adalah variabel independennya, dengan nilai signifikansi 0,002 lebih kecil daripada $0,05(5 \%)$, maka variabel Independen/bebas yaitu Metoda Pembelajaran dapat memprediksi variabel dependen yaitu Preferensi Risiko. Tetapi Nilai Korelasi 0,151 $<0,50$ ini artinya korelasinya lemah. Bisa dikatakan bahwa Metoda Pembelajaran tidak begitu memberikan dampak dalam upaya memprediksi Preferensi Risiko. 
6. Analisis Korelasi Uncertainty Coefficient Symmetric atau kedua variabel setara, maka besar korelasinya adalah 0,120 atau korelasi yang cukup lemah karena nilainya kurang dari 0,50. Angka signifikansinya adalah 0,02 atau di bawah 0,05 yang berarti kedua variabel berhubungan secara nyata.

7. Analisis Korelasi Uncertainty Coefficient Metoda Pembelajaran Dependent, dimana Metoda Pembelajaran sebagai variabel dependen (tergantung) dan Preferensi Risiko adalah variabel independennya, dengan nilai signifikansi 0,002 lebih kecil daripada 0,05 (5\%), maka variabel Independen/bebas yaitu Preferensi Risiko dapat memprediksi variabel dependen yaitu Metoda Pembelajaran. Tetapi Nilai Korelasi 0,116 < 0,50 ini artinya korelasinya lemah. Bisa dikatakan bahwa Preferensi Risiko tidak begitu memberikan dampak dalam upaya memprediksi Metoda Pembelajaran.

8. Analisis Korelasi Uncertainty Coefficient Preferensi Risiko Dependent, dimana Preferensi Risiko sebagai variabel dependen (tergantung) dan Metoda Pembelajaran adalah variabel independennya, dengan nilai signifikansi 0,002 lebih kecil daripada 0,05 (5\%), maka variabel Independen/bebas yaitu Metoda Pembelajaran dapat memprediksi variabel dependen yaitu Preferensi Risiko. Tetapi Nilai Korelasi 0,124<0,50 ini artinya korelasinya lemah. Bisa dikatakan bahwa Metoda Pembelajaran tidak begitu memberikan dampak dalam upaya memprediksi Preferensi Risiko.

Tabel 4. Metoda Pembelajaran Memprediksi Preferensi Risiko

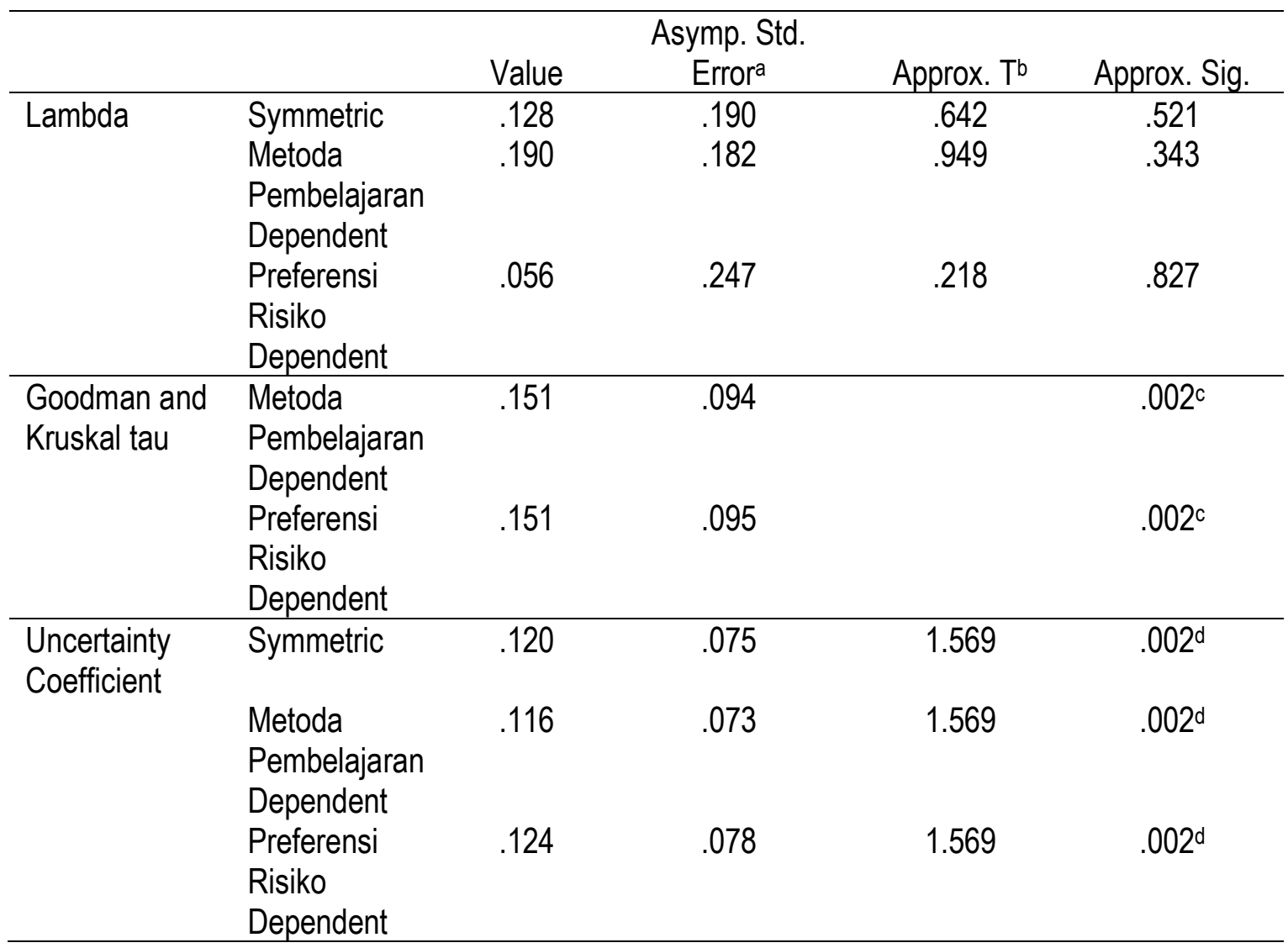


Symmetric Measures menggunakan 3 ukuran untuk mengukur korelasi antara kedua variabel yaitu Phi, Cramer's V dan Contigency Coefficient. Dari tabel Symmetric Measures dapat disimpulkan:

1) Nilai signifikansi Phi, Cramer's V dan Contigency Coefficient 0,001 lebih kecil dari 0,05 , maka dapat disimpilkan bahwa terdapat korelasi antara Metoda Pembelajaran dengan Preferensi Risiko.

2) Besaran Nilai korelasi Phi dan Cramer's $V$ menghasilkan angka sama yaitu 0,389 . Sedangkan Nilai korelasi Contigency Coefficient menghasilkan angka 0,362 (lebih kecil dari Nilai korelasi Phi dan Cramer's V)

3) Dari ketiga besaran itu dapat disimpulkan adanya korelasi yang cukup kuat antara antara Metoda Pembelajaran dengan Preferensi Risiko (disebut "kuat" jika mendekati angka 1 dan "lemah" jika mendekati angka 0).

\section{REKOMENDASI KEBIJAKAN}

Berdasarkan hasil dan pembahasan dapat disimpulkan bahwa Metoda Pembelajaran Akuntansi Berkorelasi Terhadap Preferensi Risiko Mahasiswa Dalam Pemilihan Karir. Saran untuk penelitian selanjutnya adalah:

1. Penelitian selanjutnya dengan menambahkan variabel penelitian yang secara teori terkait dengan Preferensi Risiko, Metoda Pembelajaran Akuntansi Keperilakuan dan Pemilihan Karir.

2. Meneliti mengenai korelasi antara Preferensi Risiko, Metoda Pembelajaran Akuntansi Keperilakuan dan Pemilihan Karir dengan menggunakan metoda analisis yang berbeda dan terbarukan.

\section{DAFTAR PUSTAKA}

Kusuma, Indra Wijaya. (2003). Topik Penelitian Akuntansi Keperilakuan dalam Jurnal Behavioral Research In Accounting (BRIA), Jurnal Bisnis dan Akuntansi. Volume 5, Nomor 2. Yogyakarta.

Lubis, Arfan Ikhsan. (2010). Akuntansi Keperilakuan (Edisi 2). Jakata: Salemba Empat.

Riley, W. B., \& Chow, K. V. (1992). Asset Allocation and Individual Risk Aversion. Financial Analysts Journal 48, CFA Institute 